\title{
Awareness and Usage of Online Research Facilities by Faculty Members
}

\author{
K. Meenakshi, H. S Rupa H. S. Dhanalakshmi
}

\begin{abstract}
Online has become a platform for many scholars to update and share information in order to enrich and upgrade their research knowledge. Research plays a pivotal role in the career of the faculty members. Researchers visit library not to read books or journal they have an access only to e-journal. Only digital forms of information's are demanded by the faculty members. Research plays a vital role not only for the academician but it is also very important for the business to compete in this competitive world. The purpose of this paper is to know the awareness and usage of online research facilities by the faculty members and to motivate them to use online very effectively for their research purpose. A good research should try to fill the gap of the previous researchers and also provide a good platform for the future researchers. Researcher should try to address the new problems and come out with the valuable suggestion instead of digging the same problem addressed by the various researchers. The paper concludes that the faculty members should explore more opportunities with the help of internet in order to enrich the research knowledge.
\end{abstract}

\section{INTRODUCTION}

Research plays a pivotal role in the career of the faculty members. Only with the help of research knowledge the management determines the salary, promotion, permanent, hike etc. Research should be a continuous process and ever ending process in the life of the academicians. A good research should try to fill the gap of the previous researchers and also provide a good platform for the future researchers. Researcher should try to address the new problems and come out with the valuable suggestion instead of digging the same problem addressed by the various researchers. Many researchers are not doing the research with full involvement and they are doing for the attainment of some specific purpose like getting degree, salary hike, promotion, to get job etc. They should enjoy in doing research, learning new aspects and enriching knowledge.

Faculty members should try to update knowledge related to their area of interest otherwise they will be outdated and cannot able to handle the classes very effectively. The curriculum are been updated according to the latest amended in order to keep the students face and survive this competitive world. Faculty members can enrich their research knowledge through publishing their research work

Revised Manuscript Received on September 10, 2019.

Mrs. K. Meenakshi, Assistant professor , Department of Business Administration, SDNB Vaishnav College for Women,

Chrompet,Tamilnadu, India.

(email: meenakshi.kanagarajan@gmail.com)

Dr. H. S Rupa, Assistant professor, Department of Business Administration, SDNB Vaishnav College for Women, Chrompet, Tamilnadu, India.

(email: raajiroopa@yahoo.co.in)

Mrs. H. S. Dhanalakshmi, Assistant professor, Department of Commerce, Government First Grade College,Bilikere, Hunsur, Mysore, Karnataka, India.

(email: sendhanuj@gmail.com) in reputed journals, writing books in their area of specialisation, doing minor and major projects by obtaining grants from funding agencies, attending conferences, seminars, symposium, guiding the researcher in pursuing M.Phil and PhD etc. Through LinkedIn and academia researcher can share their views, opinion and gain knowledge about the research. Now a days with the help of internet and through online knowledge are been updated and improved even a certificate courses can be learnt from through online eg (NPTEL courses are offered in all the streams).

Many funding agencies are ready to fund for minor and major projects. The researchers are not coming out with the proposal to avail those golden opportunities. They fail to allocate time for research and updating their research knowledge. Due to poor network connection, laziness of the researchers, less interest to attend the conferences all theses decrease the knowledge and the quality of research.

Researcher has to access to online in order to do their research works. Online provide a wide access to information and help to do research activities effectively.

a) Google forms: It is a survey collection application. It helps to collect information from the respondents with less cost.

b) Inflibnet: Information and Library Network Centre. . INFLIBNET help in promoting research information among scholars in India.

c) Plagiarism checker: With the advent of information and communication technology, the data are available in the online. There is a chance of getting information copied as such. It is not ethical for the researcher.

d) Google: it is most visited website by the researcher. To have an access of any kind information the researcher can login in into Google to collect research information like introduction, review of literature etc.

e) SPSS Software: Data were analysed with the help of SPSS software. Tools are provided for the research only through SPSS.

\section{REVIEW OF LITERATURE}

1. Singh Gagan \& Pant Rakesh (2013) Information has been playing a vital role in present era. After the creation of internet, it is growing day by day, covering all the fields related to knowledge. It would be helpful for learners to gain information. This study helps us to know about the importance of current and accurate information in one's respected field and by what other ways it would be 
beneficial for their purposes and does internet be allowed as a major source of organized information source for education. The internet has become an important component in the academic institutions as it plays a pivotal role in gathering information and communication needs of institutions and individuals. It has been finds out in the present study that the majority of students $(92.30 \%)$ have good using internet exposure.

2. Darries (2004) discusses issues related to Internetbased reference. An electronic survey was conducted using the web and e-mail to distribute the questionnaire. The target population was the heads of reference services at large libraries and the directors at smaller libraries of the 36 higher education institutions in South Africa. These results showed that all libraries surveyed have internet access, and all but one provided access to their users. It has been find out in the present study that librarians had access to the internet for a longer period than their users

3. Khan (2012), conducted a study on "Use of Information Sources by Faculty Members, Research scholars and Students of the Faculty of Commerce, AMU, Aligarh: A Survey" The purpose of this study is to find out the level of use of information sources by faculty members, research scholars and students of the faculty of commerce, AMU, Aligarh. The survey reveals that the maximum number of Faculty Members as well as Research Scholars uses Journals for getting their required information, while Students prefer general books for getting their required information

\section{OBJECTIVES OF THE STUDY}

To study the demographic profile of the faculty members in Chennai city.

To find out the awareness and usage of online facilities for research.

To offer suggestions to improve research knowledge among the faculty members.

\section{RESEARCH METHODOLOGY}

The researcher has used descriptive sampling technique. The sample size is 150 and the sample respondents for the study are the faculty members working in aided and self support stream of colleges in Chennai city. Researcher used convenient sampling techniques to collect data. Data was analysed with the help of Statistical packagesThe tools like percentage, chi- square, Garatte ranking, correlation and Likert summated scaling were used to analyse the data.

\section{ANALYSIS \& RESULTS}

Table 1. DEMOGRAPHIC PROFILE OF THE RESPONDENTS

\begin{tabular}{|l|l|l|}
\hline Attribute & $\begin{array}{l}\text { No. of Respondents } \\
(\mathbf{1 5 0})\end{array}$ & Percentage \\
\hline Age & 25 & \\
$21-25$ years & 40 & 17 \\
26- 30 years & 85 & 27 \\
Above 30 years & 55 & 56 \\
\hline Gender & 95 & 37 \\
Male & 105 & 63 \\
Female & & 70 \\
\hline Marital Status & & \\
Married &
\end{tabular}

\begin{tabular}{|l|l|l|}
\hline Unmarried & 45 & 30 \\
\hline Type of Family & 110 & 73 \\
Nuclear & 40 & 27 \\
Joint Family & & \\
\hline Educational Qualification & 96 & 64 \\
M. Phil & 54 & 36 \\
PhD & & \\
\hline Stream & 52 & 35 \\
Aided & 98 & 65 \\
Self financing & & \\
\hline Designation & 65 & 43 \\
Assistant Professor & 38 & 25 \\
Associate Professor & 47 & 32 \\
Professor & & \\
\hline Years of Experience & 30 & 20 \\
1 - 5 years & 51 & 34 \\
6-10 years & 69 & 46 \\
Above 10 years & & \\
\hline Income per month & 60 & 40 \\
Less than 20,000 & 38 & 25 \\
20,000 - 40,000 & 52 & 35 \\
Above 40,000 & 84 & 56 \\
\hline Hours Spend for research & & 26 \\
Less than 5 hrs a month & 39 & 18 \\
6-10 hrs a month & 27 & \\
More than 10 hrs a month & & \\
\hline
\end{tabular}

Source Field Survey - August 2019

Chi -Square:

Ho: The level of usage of online research facilities was dependent of age, gender, marital status, types of family, educational qualification, designation and years of experience.

Ha: The level of usage of online research facilities was not dependent of age, gender, marital status, types of family, educational qualification, designation and years of experience.

The calculated ?2 values were given in the following table 2

\section{TABLE 2 \\ ASSOCIATION BETWEEN LEVEL OF USE OF ONLINE FOR RESEARCH WITH SOCIAL FACTORS}

Source : Field survey August 2019
\begin{tabular}{|c|l|c|c|l|l|}
\hline S.No & \multicolumn{1}{|c|}{ Variable } & $\begin{array}{c}\text { Calculated } \\
\text { values }\end{array}$ & $\begin{array}{c}\text { Degrees of } \\
\text { freedom }\end{array}$ & $\chi^{2} 0.05$ & Inference \\
\hline 1 & Age & 9.61 & 4 & 9.30 & Reject $\mathrm{H}_{\circ}$ \\
\hline 2 & Gender & 76.50 & 8 & 17.60 & Reject $\mathrm{H}_{\circ}$ \\
\hline 3 & Marital status & 10.07 & 2 & 5.99 & Reject $\mathrm{H}_{\circ}$ \\
\hline 4 & Type of family & 7.58 & 2 & 5.99 & Reject $\mathrm{H}_{\circ}$ \\
\hline 5 & $\begin{array}{l}\text { Educational } \\
\text { Qualification }\end{array}$ & 34.09 & 22 & 33.92 & Reject $\mathrm{H}_{\circ}$ \\
\hline 6 & Designation & 6.30 & 2 & 5.991 & Reject $\mathrm{H}_{\circ}$ \\
\hline 7 & Years of experience & 62.50 & 4 & 42.65 & Reject $\mathrm{H}_{\circ}$ \\
\hline
\end{tabular}

Comparing the calculated values $\chi^{2}$ with the theoretical values of $\chi_{0.05}^{2}$, it was inferred that the level of usage of online research facilities was not dependent on age, religion, caste, marital status, size of family and type of family .

TABLE 3: IMPROVE QUALITY OF RESEARCH GARATTE RANK

\begin{tabular}{|l|l|c|l|}
\hline S. No & Variables & Score Value & Rank \\
\hline 1 & Google forms & 56.19 & 5 \\
\hline 2 & Plagarism Checker & 70.48 & 3 \\
\hline 3 & Google & 83.7 & 1 \\
\hline 4 & Inflibnet & 65.82 & 4 \\
\hline 5 & SPSS Software & 76.19 & 2 \\
\hline
\end{tabular}

Source Field Survey - August 2019 


\section{Interpretation}

From the above table it is inferred that the quality of research is improved: Google ranked first with the score of 83.7, followed by SPSS software with the score of 76.19, followed by plagiarism checker with score of 70.48 , followed by Inflibnet with a score of 65.82 and Google forms with a score of 56.19 respectively.

TABLE 4: IMPROVE RESERACH KNOWLEDGE MEAN SCORE

\begin{tabular}{|c|l|c|c|}
\hline S. No & Improve Research Knowledge & Score Value & Rank \\
\hline 1 & Publishing articles & 3.50 & 7 \\
\hline 2 & Writing book & 3.74 & 6 \\
\hline 3 & Minor project & 3.82 & 5 \\
\hline 4 & Major project & 3.90 & 4 \\
\hline 5 & Attend conferences & 4.10 & 1 \\
\hline 6 & Guiding research scholars & 3.95 & 3 \\
\hline 7 & Interact with expert & 4.02 & 2 \\
\hline \multicolumn{2}{|c|}{ Mean Score } & $\mathbf{3 . 8 6}$ \\
\hline
\end{tabular}

\section{Interpretation}

Research knowledge of the researchers are improved are determined on the basis of mean score which came out to be 3.86. The factors like attending conferences, interact with expert,

Guiding research scholars and major projects have mean score exceeding 3.86. However the factors like minor project, writing book and article publishing have mean score less than 3.86 which conclude that these factors were considered as less as compared to previous factors

TABLE 5 CORRELATION : RELEATIONSHIP AMONG TYPE OF FAMILY AND IMPROVEMENT IN RESEARCH KNOWLEDGE

\begin{tabular}{|l|l|l|l|l|}
\hline & Value & $\begin{array}{l}\text { Asymp Std } \\
\text { Error }\end{array}$ & Approx T & Approx Sig \\
\hline Pearson's R & .912 & .009 & 34.918 & .000 \\
\hline $\begin{array}{l}\text { Spearman } \\
\text { Correlation }\end{array}$ & .900 & .013 & 32.541 & .000 \\
\hline No of valid cases & 150 & & & \\
\hline
\end{tabular}

Based on normal approximation

Inference: There is highly positively correlated between type of family and improvement in research knowledge.

\section{RECOMMENDATIONS}

* Institutions should encourage faculty members to undertake minor and major projects and get fund from the funding agencies.

* Management should motivate the faculty to publish articles in UGC referred journals.

* Faculty members should be properly recognized when they complete their research courses and when are publish articles in reputed journals.

* Management should encourage the faculty members to attend workshops, seminars, conferences, symposiums, FDP etc in order to enrich the knowledge of the research.

* Research knowledge of the faculty can be improved only through interaction with experts.

* Faculty members should allocate a separate time for research to update and enrich their research knowledge.

* Institution should subscribe e - journal and print journal and should be available in the library for the access of the faculty members.
* Support from family members to improve their research knowledge like permitting them to attend conferences, allowing them to carry their research work at home etc.

\section{CONCLUSION}

Online is one the best source to get all information with a single click. Faculty members should try to update knowledge related to their area of interest otherwise they will be outdated and cannot able to handle the classes very effectively. It is inferred that they have spend only less time for research, in order to improve their knowledge they should allocate more time to enrich their knowledge which is needed for the success of the academician. Institution and family members should motivate and support them to carry out their research activities. Faculty members are aware and have good knowledge of using internet. They should try to use it very effectively in order to do their research work.

\section{REFERENCES}

1. Singh Gagan \& Pant Rakesh, "Use of Internet for Research and Educational Activities by Research Scholars: a Study of DSB. Campus of Kumaun University-Nainital", International Journal of Engineering and Management Sciences · January 2013.

2. Darries, Fatima (2004), "Internet access and use in reference services in higher education institutions in South Africa", South African Journal of Library and Information Science, Vol. 70 No. 2, pp. 72-85.

3. Khan, Abdul Mannan, (2012), "Use of Information Sources by Faculty Members, Research scholars and Students of the Faculty of Commerce, AMU, Aligarh: A Survey", Library Philosophy and Practice (e-journal), Paper 782. 